From this statement founded on very satisfactory experiment it is apparent that the bar man may very well offer to deliver his drinks without additional charge for the cooling.

It becomes necessary to establish with one of the most conspicuous bar keepers a jar and give him his ice for a year

Thus when people are able to get cool drinks for the same price as the warm, the prejudice against cold drinks will be overcome.

The object is to make the whole population use cold drinks instead of warm or tepid and it will be effected in the course of three years. A single conspicuous bar keeper having one of the jars and selling steadily his liquors all cold without an increase in price, render it absolutely necessary that the others come into it or lose their customers - they are compelled to do what they could in no other way be induced to undertake.

\title{
Council for the Preservation of Business Archives
}

During the year 1934, a sister organization to the Business Historical Society, known as the Council for the Preservation of Business Archives, was formed in London, England. The Council officially came into being on May I I, I934 when a group of influential men of England gathered at the London School of Economics and Political Science for the Foundation meeting. A great deal of preliminary work had been done in the preceding two or three years, but the organization meeting was the first public notice given the enterprise.

According to the rules adopted at the inaugural session, the objects of the Council shall be:

$a$. To promote the preservation of archives which bear upon the history of commercial and industrial enterprise and of economic relationships generally; to further their accessibility to students; and to collect information which will promote these aims.

b. To accept responsibility at discretion for archives which cannot otherwise be rescued from oblivion.

c. To appoint corresponding members for regional activities.

$d$. To undertake such publications as may further the objects of the Council.

$e$. To establish a fund or funds to enable the objects of the Council to be carried out. 
A pamphlet, "History from Business Records," published by the Council explains the factors that have led to the establishment of the society and also elaborates on the purposes. "It is not generally realised by firms and business men in possession of old ledgers, correspondence, and other business records that these documents contain unique material of high value for the study and advancement of business history. They are of value not merely as testimony to continuity and tradition of the economic history of this country and its commercial relations abroad. They are worth preserving. ...

"Every year masses of old records are burnt or sent to be pulped. Catastrophic onslaughts are made on them, prompted by lack of storage space, reorganisations, removals, and so on. ...

"It (the Council) has been founded to act both as a source from which advice may be obtained by owners of documents and as a clearing-house for information regarding business records, and it makes provision for the safe keeping in local and central depositories of business records of exceptional historical value, surrendered or lent by their owners.

"The immediate object which the Council has set itself is to survey the field by the compilation of a register of such records. In the earlier stages of its work it proposes to confine the register primarily to documents one hundred years old or more. Already it is possible to list the names of some four hundred firms in the London district which were founded before $1830 . .$. At a later date it is hoped to bring investigations down to a more recent date."

Some indication of the manner in which the Council will conduct its activities may be obtained from a portion of a letter sent by Mr. A. V. Judges, one of the Joint Honorable Secretaries of the Council to Mr. Frank C. Ayres, executive secretary of our Business Historical Society. "It is unlikely that we shall attempt to build up a collection of our own, unless we change our present policy, which is to find places of deposit for homeless records in the public library or the university library which serves most closely the area covered by the business recorded in the manuscripts. In the course of time homes will have to be found in London for business records of more than local importance, and there will be the British $\mathbf{M u}$ seum, the new University Library, the Institute of Historical Research, and the London School of Economics to turn to for storage space, to say nothing of other libraries. Of course in some cases we may be obliged to have the records ourselves, but we shall take 
them unwillingly. So you will see that our main scheme is to act as a go-between and a sort of catalytic agent. We intend to build up as complete a register as possible of existing business records with card indexes cross referenced according to location and type of business, and copies of these cards will be kept by our local committees or organizers when the system is built up."

Thus it may be seen that there is one essential difference between the activities of the two organizations in that the Business Historical Society actually acquires and centralizes the records and manuscripts in the Baker Library, whereas the Council does not actually collect or attempt to centralize the records. The Council will expand its activities through local committees and the appointment of volunteer organizers in the larger industrial areas with the intention of utilizing depositories at the point of origin of the records. The small size of the English Isle makes such a plan feasible there; for research students can conveniently go to any depository in the country. However, in this country if business records are to be accessible to students, it is almost essential that they be centralized at least by regions and at points close to centers of research.

The Business Historical Society heartily welcomes the Council for the Preservation of Business Archives, and hopes that the common interests of the two groups will lead to a mutually beneficial cooperation in the study of business history. In respect to the possibilities of cooperation between the two organizations it is interesting to note a letter recently addressed to the Society by Professor G. N. Clark, Chairman of the Council.

Dear Sir:

29 September 1934

Many thanks for your kind and encouraging letter conveying the good wishes of your Society to this Council. I was very much interested when I visited the Baker Library a few years ago in what I heard about the work of your Society and as our work develops I feel sure we shall find it a great advantage to be able to draw on your experience. Our aims are closely similar and though our present programme has to be somewhat cautious I hope we may regard ourselves as a sister body. I need hardly say that if we can be of any assistance to you we shall be most ready, and we are grateful for your approach.

Yours very truly,

G. N. Clark (signed). 
The official headquarters of the Council is the Institute of Historical Research, Malet St., W.C. I, London, England. In addition to this correspondence headquarters, the Council will utilize certain facilities provided by the London School of Economics and Political Science for storage and office work.

\section{Wooden Money}

IN THE forest region of the State of Washington lying south of the Capital, Olympia, there is a little town, Tenino, that has been receiving in the last three years an amount of newspaper publicity far out of proportion to its size. And well might this be so, for Tenino has added a new page in the history of currency by issuing wooden money, some of which has found its way into the archives of the Society.

It all came about when the Citizens' Bank, the only bank in Tenino, closed its doors on December 7, I931, leaving the community in a precarious monetary situation. Rising to the emergency, the Chamber of Commerce of the town authorized the bank liquidator to issue certificates to the depositors to the extent of twenty-five per cent of their deposits and in turn agreed to accept the deposit certificates in a trusteeship against which scrip was issued.

Now the issuance of scrip is nothing new in currency annals, but Tenino not only issued $\$ 25, \$ 10$, and $\$ 1$ notes in the customary paper notes, but it also issued 5 ot and $25 \boldsymbol{c}$ notes printed on twoply slicewood. Each piece of wooden money was made of two oneeightieth-inch slices of wood bound together by a sheet of paper, thus making the composition strong and pliable.

Whether it was foreseen or not, the Tenino Chamber of Commerce found that there was a huge market for wooden money among coin and souvenir collectors. The new currency was so popular that it was drawn out of town and was replaced by official United States money. As a matter of fact there was such a huge external demand for the wooden tokens that they actually had to be withdrawn from circulation in the town. Wisely the Chamber of Commerce had set January I, I933 as the final redemption date for the currency, and when that day came they were only asked to redeem $\$ 30$ out of the $\$ 6,500$ issued; the balance remained in the 